\title{
COMMENTARIES: AN OVERVIEW OF THE TRUDEAU CONSTITUTIONAL PROPOSALS
}

\begin{abstract}
In response to Professor Simeon's overview of the Trudeau Resolution, Alan C. Cairns and Garth Stevenson discuss different aspects of the constitutional proposals. Professor Cairns makes seven observations on the process of constitutional reform, touching on the various stages involved, the Charter of Rights, an historical comparison between events preceding the B.N.A. Act and events occurring in response to the current reform proposals, and the role to be played by the Canadian people. Professor Stevenson adopts a federalist position and, in contrast to Professor Simeon, concludes that the method of presentation, content and possible omissions of the federal constitutional proposals are not fatal to their success.
\end{abstract}

ALAN C. CAIRNS*

The conventional response to Professor Simeon's paper would be to present a tightly organized analysis, to make intellectually coherent the chaotic events which pass for constitution-making in contemporary Canada. Since we might not unfairly castigate our politicians for having transformed the constitutional order of the fifties into the constitutional chaos of the seventies and eighties, it would be aesthetically appealing, a kind of one-upmanship, to impose an analytical order on their contributions to our disintegrating constitutional system. It has proved even more tempting, however, to describe chaos on its own terms, to respect the frantic "ad hocery" in Ottawa, the provincial capitals, and London by providing a series of seven disconnected observations. These may not constitute a McLuhan probe, or an Innisian kaleidoscope, but as fragmentary, somewhat random juxtapositions they may produce some insight.

I.

The willing and unwilling participation of academics in the constitutional process should not be overlooked. Many of the academics at this conference have been involved in one way or another with the governments engaged in the pursuit of constitutional change. In my own case this has been restricted to a part-time involvement as a member of an academic advisory committee to the British Columbia Cabinet Committee on Confederation.

A striking, positive example of the academic role is that of Professor William Lederman of Queen's University, a frequently cited authority in the briefs prepared by the dissenting provinces for the United Kingdom Kershaw Committee, and for the court challenges to the proposed federal Resolution. Before the earlier 1978 Special Joint Committee on the Constitution of Canada, Professor Lederman played a key part in setting in motion the political and judicial process which ultimately led to the Supreme Court reference on the Senate, and the court's finding that the Liberal government's Senate proposals in Bill C-60 were beyond the power of Ottawa.

Lederman has played his role as an academic, providing detached objective analysis, albeit as a very visible participant. At a different level there is the slow filtering of ideas from the academic community into the minds of political actors. The classic example here is the emergence from the obscurity of a

\footnotetext{
* Professor of Political Science, University of British Columbia.
} 
1971 academic article by Donald V. Smiley ${ }^{1}$ of the concept of instrastate federalism which has, in a decade, become little short of a new conventional wisdom to one school of constitutional reformers.

The boundaries between academic and political life are constantly being breached, in both directions. There are pervasive pressures and temptations for academics to take sides. In pursuit of their objectives politicians will exploit and manipulate academics as they seek to legitimize their constitutional positions. In these circumstances, academics have an obligation to seek objectivity, to avoid seeking cheap publicity, and to sit courageously on the fence where appropriate.

A horrifying example of the dangers posed to academic life by the constitutional crisis was recently provided by the public labelling of academics who appeared before the Joint Committee as Liberal, N.D.P., or Conservative experts - a deplorable departure from the previous assumption that scholars gave evidence as scholars.

II.

The process of constitution-making was dramatically transformed by the migration of the constitutional discussions from the intergovernmental meetings in July, August, and September to the televised Joint Committee hearings from November 1980 to February 1981. Throughout the summer, the proceedings were dominated by governments claiming to speak for people and pursuing the interests of governments. As the scene shifted to the Joint Committee hearings profound changes in focus, style, and demands were immediately evident.

Part of the difference sprang from the reduction of the original summer agenda of twelve items to a more restricted package which, in its original form, included only patriation, an amending formula, equalization, and a Charter of Rights. The shift to the parliamentary forum and the Joint Committee had major consequences beyond the narrowing of subject matter. It gave the national parties a prominence they had lacked in the lengthy summer discussions between governments, and it deprived the provincial governments of a prominence they had enjoyed. Provincial interests were necessarily more visible in an intergovernmental bargaining context than in a federal parliament with a Liberal majority and a supportive third party, the N.D.P., which had not entirely rejected the centralism of its founders. Provincial visibility was not helped by the strategy decision of most provinces not to appear before the Joint Committee, but instead to try and block the federal package by resort to the courts and lobbying in the United Kingdom.

The opening up of the process brought in the public in the form of interest groups, particularly ethnic organizations and civil rights advocates. The cumulative effect of these factors was to make the concerns of provincial governments suddenly of much less importance. The Charter, which had received at best only a lukewarm reception from provincial governments all summer, was the focal point of most citizen groups. Not only were they over-

1. Donald V. Smiley, "The Structural Problem of Canadian Federalism" (1971) 14 Canadian Public Administration 326. 
whelmingly in favour of a charter, but they exerted very strong pressure and lobbied skilfully to get a charter much less respectful of parliamentary supremacy than the first version presented to the Joint Committee, and they succeeded to a truly remarkable extent.

III.

The appearance of aggressive citizens' groups and civil rights proponents of entrenchment set the stage for a direct conflict between provincial governments and the vociferous advocates of a charter with teeth in it. In fact, so smoothly and inexorably did the scenario unfold that it is difficult not to assume that it was all manipulated by $\mathrm{FPRO}^{2}$. The sequence of events went like this: the federal government initially devised a charter with an introductory clause ${ }^{3}$ designed to placate those provinces, the majority in fact, which were opposed to anything more than a weak and limited charter. Inevitably, the Charter quickly became the centrepiece of the hearings. Equally inevitably, those most eager to appear as witnesses were not the concerned believers in the desirability of protecting parliamentary supremacy from the encroachments of the judiciary, but those concerned with protecting the citizen against the abuse of state power, or those seeking to carve out for themselves or their clients a special protected place in the constitution with, where possible, an invitation to affirmative action on their behalf. The federal government, finding that its originally weak Charter had not elicited any additional provincial government support, rationally concluded that its limited resources of political capital were better deployed in placating the voluble critics parading before the Joint Committee. This led to a much tougher charter, one even less congenial to the unhappy provincial governments than its predecessor. Each manifestation of federal government sensitivity to the civil rights community was an insensitivity to those provincial governments opposed to a strong charter.

By the end of the Committee hearings the federal government had boxed itself in, doubtless not without some recognition that its resultant lack of manoeuverability was advantageous in its conflict with the provincial governments. The federal government, as Chrétien noted, had aroused public expectations which it could not disappoint, even if, regrettably, this required more disappointments for provincial governments.

That this scenario was entirely planned by some manipulative genius is unlikely. That its advantages were glimpsed with increasing clarity as the process unfolded is undoubted. Those critics of the federal package who suggest at this stage (mid-February 1981) that the Trudeau government should lop off the Charter and go to Britain for patriation and an interim amending formula requiring provincial unanimity for matters affecting the provinces are politically naive. To ask the federal government to drop the Charter is to ask them to give up the most popular part of their package, to betray and undermine their most vocal support base, to turn the federal N.D.P. against them, and to damage the prospect of obtaining an amending formula falling

2. Federal-Provincial Relations Office.

3. Worded as follows: "The Canadian Charter of Rights and Freedoms guarantees the rights and freedoms set out in it subject only to such reasonable limits as are generally accepted in a free and democratic society with a parliamentary system of government." 
short of a unanimity requirement. The basic federal hope, surely, must be that an amending formula with little provincial support, and a Charter which most provinces oppose will both be sustained by popular support for the latter.

IV.

If the Charter goes through in roughly the form in which it emerged from the Joint Committee, the long run effect on Canada will be profound. Section 15(2), for example, constitutes an open invitation for affirmative action programs aiming at "the amelioration of conditions of disadvantaged individuals or groups including those that are disadvantaged because of race, national or ethnic origin, colour, religion, sex, age or mental or physical disability". In this respect the new Canadian constitution will be more American than the American constitution.

Over time, the Charter will fundamentally change the Canadian political system and the very identity of the Canadian citizenry. There is an unfortunate tendency, a product of the domination by lawyers of this area of constitutional discussion, to argue the virtues or demerits of the Charter in terms of citizen/state relations, to debate the issue in terms of the best methods for protecting rights. In so doing, the American approach is contrasted with the British, leaving Canadians with the choice of being faithful to their receding imperial past, or of following the practice of the giant to the south.

While these perspectives are not useless, they ignore the profound impact of the Charter on identity and community in Canada. The Charter is not playing around with the externals of our existence. Over time the cumulative results of its application will reach deeply into our innermost being, manipulating our psyche, and transforming our self-image. Our children will be very different people because of this Charter. The Charter, by underlining our rights as Canadians, strengthens the national community against provincial communities.

The beneficial consequences from the federal government perspective will be most strikingly evident when the Charter is successfully applied against provincial governments, for in such a case a Canadian right is being protected against a provincial encroachment. But even if the Charter is successfully invoked against federal legislation there is still a gain to Ottawa. Every successful invocation of the Charter, even against the federal government itself, contributes to a sense of Canadianism. In the long run this can only strengthen the central government against the provinces.

$$
\text { V. }
$$

Professor Simeon argues that: ${ }^{4}$

How we get a new constitution is as important as what it actually contains. Its legitimacy depends on the degree of consent it can command. This Resolution, opposed by most provinces, and apparently by a majority of public opnion, lacks sufficient consent. It splits and divides us more than it unites.

That there is something in what Simeon says is undeniable. On the other hand, it is my own impression that his is an extreme interpretation, overly

4. R. Simeon, supra at 
influenced by the climate of near hysteria and exaggeration which engulfs us now and works against the long view and the cool vision. To look briefly back to 1867 and the events leading up to it is to be somewhat reassured that constitutions not born in immaculate conception may still have a capacity for survival. There was little evidence of widespread popular support for the original B.N.A. Act among those whose existence was being transformed by this elite-led drive to political union. That the people were not consulted was due not only to the belief that to do so would have been an Americanism, unworthy of an experiment whose raison d être was to ward off American encroachments, but also for the very practical reason that it was not entirely clear that the people would have responded with even a weak 'yes'. That the black drapery and bunting on the streets of Halifax, Nova Scotia on July 1, 1867, was not celebrating the new birth with joy but protesting a betrayal with anger, is a commonplace in our introductory lectures in Political Science and History dealing with the Confederation period. Further proof was provided by the first federal elections in that province which sent eighteen of nineteen Members of Parliament to Ottawa to repeal the B.N.A. Act.

This earlier exercise in constitution-making was thus not without its blemishes if measured by the criteria applied by some critical observers of the present exercise. The manipulative role of British governors in Nova Scotia and New Brunswick was not irrelevant to the achievement of Confederation. More generally, the basically sympathetic support of the British government for the political regrouping of her British North American colonies was an immensely helpful external impetus to the creation of a new country. Yet in spite of all the shortfalls from perfection that accompanied its formation, the British North America Act, now in its 114th year, has some claim for inclusion in the Guinness Book of Constitutional Records.

The comparison between 1867 and the present should not be pushed too far. Contemporary circumstances are different. The strong opposition of powerful provincial governments to the Trudeau Resolution had no exact counterpart in the 1860's, partly of course because those most opposed did not then immediately join the new nation. Nevertheless, it is not impossible to look ten years down the road and see a Canada with an entrenched Charter, an amending formula very much like the one now proposed by Ottawa, a Canada with someone other than Trudeau at the helm, and a Canada in which the changes embodied in the Trudeau package have become part of the accepted fabric of Canadian political life.

\section{VI.}

In the closing pages of his presentation Professor Simeon tellingly observes that most Canadians do not wish to choose between competing provincial and federal government visions of the country's future. We live easily with our dual loyalties at the grass roots level. "I doubt," he concludes, "that the polarization we see now between governments is shared by most citizens." This is a profound observation. It undermines the academic model of "consociational democracy" which has enjoyed some popularity in Canadian studies, and which suggests that Canadians are a divided people

5. Id. at 
held together by political elites who have stitched a thin fabric of consensus across the regional fissures and cleavages allegedly characteristic of the underlying society.

The opposite is more nearly true - that we are a united people divided by our governments. This, it can even be suggested, is in the very nature of contemporary Canadian federalism. In pursuing his objectives, and responding to the self-interested cues emanating from the pyramid of political and bureaucratic power over which he presides in Ottawa, $\mathrm{Mr}$. Trudeau is driven to exaggerate the Canadian component of our identities. He has no responsibility for our various provincial existences. Indeed, in some circumstances our provincial identities may be seen as a threat to his larger political goals. It is equally logical and natural for our provincial leaders to exaggerate the provincial components of our identity. They have no responsibility for our national identity although they cannot completely disregard it, as even Mr. Levesque recently discovered. Thus, political leaders at the two levels, by the very nature of the roles they play, are driven to this exaggeration, to this onesidedness. In the division of labour between governors and governed, the forces of unity are more deeply rooted in the underlying society than in the competing and governing elites of the federal system.

\section{VII.}

Finally, let us enjoy the spectacle. We are being provided with brilliant spectator sport. The greatest juggler in the world could not keep so many balls in the air at once. Consider the following:

a.) Courts in three provinces, in a staggered sequence, ruled on the constitutional legality of the proposed federal Resolution. Offstage the Supreme Court awaited the final act of the judicial play in which it will be called upon to respond to the inevitable appeals from the provincial courts.

b.) The Joint Committee was elbowed off the stage after extending its time in the limelight from the original early December deadline to the middle of February. In the Joint Committee three parties from two Houses danced before the television cameras in that curiously mingled search for political advantage and the public good characteristic of partisan activity.

c.) The debate returns to the House of Commons and the Senate. The Senate, through its Joint Committee members, has already managed, by securing an appropriate amendment, to eliminate the threat to its survival contained in the original proposal, which gave it only a suspensive veto. The communication to the Liberal cabinet that the Resolution itself might encounter difficulties in the Senate should an absolute Senate veto not be restored had the desired effect.

d.) Meanwhile ten provincial premiers and ten provincial cabinets, in some cases supplemented by committee hearings or Legislative Assembly debates, have been and are plotting their strategies for and against the federal proposal.

e.) Across the Atlantic, in the United Kingdom, the Kershaw Committee issued its first report recommending against automatic British compliance with any Canadian request.

f.) Shortly, the British Parliament - both the House of Commons and the House of Lords, who may disagree with each other - will be called upon to respond to the final version of the Resolution. 
In the midst of all this, the issue of "colonialism" is raised again, threats of referenda and elections to settle the issue are heard, leaked and filched secret documents have become almost a daily occurrence, the United Kingdom High Commissioner in Ottawa has indicated he will take early retirement, and the Canadian High Commission in London insinuates that the British government is tapping its phones.

I remember the Second World War when my parents wondered if there would be any more news after that great global conflagration ended. They need not have worried.

Indeed, when we are asked in the year 2000 where we were in the great constitutional crisis of the seventies and eighties, we can proudly say that we were there, every night - with Knowlton Nash.

\section{GARTH STEVENSON*}

Hearing Richard Simeon's paper I am reminded that he now lives in Kingston, Ontario, which is well known as the home of Sir John A. Macdonald, but which also had the less familiar and less enviable distinction of being the home of Sir Oliver Mowat. It was Mowat who, as Premier of Ontario from 1872 until 1896, was largely responsible for inventing and propagating the view of Canadian federalism that Richard Simeon has presented here. In fact, if I shared the belief of the late Mackenzie King that disembodied spirits persisted and were capable of intervening in our affairs, I might conclude that the spirit of Oliver Mowat was looking over Richard Simeon's shoulder as he wrote this paper.

As Richard rightly observed, there is a fundamental conflict between two opposing views of Canadian federalism, a conflict which has become evident in the current controversy over patriation. Although he does not admit it, I think it is fair to say that Richard Simeon's view, like Mowat's, is one according to which the provinces are the fundamental building blocks of the Canadian state and society. As some of you know, and others will shortly discover, my own view is fundamentally different. I see Canada itself as the primordial reality (or community, for those enamoured of that fashionable expression) and the provinces only as territorial entities that are useful for certain purposes but not of the same order of importance as Canada itself.

Those who take the other view have a characteristic approach to the B.N.A. Act that may be exemplified by Richard Simeon's paper. First, they emphasize any provision of the Act that can be interpreted as an argument for strengthening provincial autonomy. Second, they ignore, insofar as that is possible, the far more numerous provisions intended to ensure the dominance of the central government. Third, any of these that cannot be ignored are arbitrarily declared to be "obsolete". Finally, if all else fails to produce the desired result, resort is had to the invention of entirely fictitious provisions of the Act. Two of these, or possibly the same one referred to in different ways, are mentioned in the paper just presented, namely "the domestic pro-

\footnotetext{
- Associate Professor of Political Science, University of Alberta.
} 
cess" of constitutional amendment which the federal government is accused of "bypassing" and, in a later section of the paper, "the existing amending rule". In fact, of course, there is no "existing amending rule". Certainly there is no rule requiring unanimous consent of the provinces as seems to be implied. In fact the absence of such a rule was not an oversight by the Fathers of Confederation but the logical consequence of the way in which they envisaged the roles of the two levels of government. As Sir John A. Macdonald wrote to the Lieutenant Governor of Nova Scotia in 1886:

The representatives of Nova Scotia as to all questions respecting the relations between the Dominion and Province sit in the Dominion Parliament and are the constitutional exponents of the wishes of the people with regard to such relations. The Provincial members have their powers restricted to the subjects mentioned in the B.N.A. Act and can go no further.

Richard Simeon has made the gratuitous observation that "Mr. Trudeau, oddly enough, is the Sir John A. Macdonald in the current debate". I I am not sure why this should be considered odd, and might add parenthetically that it is much odder for the Progressive Conservative party, which claims descent from Macdonald, to adopt a view of federalism that would leave us with a cross between the constitution of medieval Poland and that of the Confederate States of America during the Civil War. That is the real oddity in the current debate. However, getting back to Mr. Trudeau, he is not, strictly speaking, adopting a John A. Macdonald view. Instead he is proposing to give the provinces something which they do not now have under the B.N.A. Act, namely an explicit role in the process of constitutional amendment. In this respect the federal proposals would increase provincial powers, not reduce them.

Richard Simeon criticizes the federal proposals on three grounds: the procedure by which they are being presented, the substance of what they do contain, particularly the proposed amendment formula, and the omissions, or what they do not contain. I will deal with each in turn.

On the question of procedure I have already indicated my view that there is no binding requirement to consult the provincial governments, let alone to secure their unanimous consent. The experience of fifty-three years of negotiations strongly suggests that the provincial governments will never agree on the terms and conditions of patriation except in return for additional powers and other concessions that would make the country ungovernable. Quebec, which is actually given a veto by the Victoria amendment formula, was the only province to reject that formula ten years ago, and did so because of a controversy over social policy, not because of an objection to the formula itself. More recent negotiations have produced further demands by provinces that agreed to the formula and patriation in 1971 for additional concessions on fisheries, resources, communications and so forth. This game could go on forever, and the federal decision to bring it to an end is fully justified in the circumstances. The so-called "unilateral" procedure is being used only once, and thereafter an amendment formula similar to that of other federations will be used. Moreover, the federal government is being moderate in seeking only limited substantive changes at this time, apart from the Charter of Rights which most Canadians support in principle. 
Richard Simeon argues that patriation did not take place in 1931 because "we" could not agree on an amendment formula at that time. One may ask why the pronoun "we" should be used in this connection. What he really means is that provincial governments could not agree with the federal government. The people of Canada never had a chance to indicate whether they could agree or not. This time, in contrast, they will be able to choose in a referendum between the amendment formula preferred by the federal government and an alternative approved by the provincial governments, assuming that seven provincial governments are able to agree on one.

This brings me to the question of the amendment formula contained in the Resolution, which seems to me a perfectly reasonable one. It may be noted again that most provinces agreed to a similar formula in 1971, that this one will not take effect for two years, during which time no amendment will be possible without the unanimous concurrence of the eleven governments, and that the provincial governments will have time to propose an alternative, with the people making the final decision.

For reasons which I find inexplicable, many otherwise reasonable people, including Richard Simeon, appear singularly distressed by the provision for amendment by referendum as an alternative to approval by the provincial legislatures. The experience of Mr. Levesque in the recent Quebec referendum hardly supports the frequently heard assertion that a government which frames a referendum question can determine its outcome. Moreover, the Australian constitution is always amended by referenda, with the governments and legislatures of the individual states having no formal involvement in the process. The Australian voters have turned down the vast majority of the proposed amendments put to them by the federal parliament. The fear of constitutional referenda expressed by some of our provincial premiers suggests that they do not believe the people of their provinces can be trusted to uphold provincial interests.

Finally, I must deal with Richard Simeon's complaint that the proposed Resolution does not include some of the provisions he would like to see. There is something of a contradiction here; since he objects in principle to the procedure which is being used one would expect him to prefer that the package of substantive changes be as limited as possible in content. There will be time later to deal with the other questions he raises, such as the restructuring of federal institutions and the redefinition of legislative powers. Some of his ideas are interesting, although I do not think that the restructuring of federal institutions is a panacea that will resolve all of our problems.

Like many other people, Richard Simeon is unhappy because the federal government is proceeding with proposals about which there are strong differences of opinion. Surely this is what politics is all about. If we all agreed on everything we would not need politics or a state. Politics means conflict and controversy, winners and losers. Those who find this fact unpleasant should abandon political science and study theology instead.

More specifically I would suggest that every major initiative in Canadian history, such as Confederation itself, the building of the transcontinental railways, the development of the welfare state, the institution of bilingualism, and even the admission of Newfoundland as a province, was bitterly resented and resisted by large numbers of people. Today we accept all of these things. I foresee that twenty years from now, when these constitutional reforms have become realities, people will look back at the present debates and wonder what all the fuss was about. 